\title{
Evaluation of Selected Cucurbitaceous Vegetables for Resistance to Zucchini yellow mosaic virus
}

J. Svoboda and L. Leisova-Svobodova, Crop Research Institute, Drnovská 507, 161 06, Prague 6, Czech Republic; and M. Amano, Saitama Gensyu Ikuseikai Co. Ltd., 2616 Niibori, Kuki, Saitama 346-0105, Japan

\begin{abstract}
Svoboda, J., Leisova-Svobodova, L., and Amano, M. 2013. Evaluation of selected cucurbitaceous vegetables for resistance to Zucchini yellow mosaic virus. Plant Dis. 97:1316-1321.

Zucchini yellow mosaic virus (ZYMV) causes considerable losses of cucurbitaceous vegetables grown nearly all over the world; indeed, the commonly planted cultivars are highly susceptible to ZYMV. In all, 3 cultivars of American and 8 of European summer squash (Cucurbita pepo), and 6 Japanese and 21 European cucumber lines (Cucumis sativus), including both slicing and pickling species, were selected for the evaluation of their resistance to the most virulent Czech strain, ZYMV-H (GenBank accession number DQ144054). Butternut squash (Cucurbita moschata) 'Menina 15', Chinese slicing cucumber 'Taichung Mou Gua-1' (TMG-1), and watermelon (Citrullus lanatus) accession PI 595203 were included in the experiment, because they were

reported to be resistant to ZYMV. The tested plants were mechanically inoculated by ZYMV-H and their resistance was assessed through a comparison of the relative virus protein concentrations and visual symptoms. Butternut squash Menina 15, Chinese slicing cucumber TMG-1, Japanese slicing cucumber breeds 'G22' and 'A192-18', and watermelon PI 595203 were evaluated as immune: the virus concentration in their leaves was zero, as verified by polymerase chain reaction. American summer squash 'Cougar' and Japanese slicing cucumber breeds 'A202-18', 'R10', and 'S93-18' were clearly resistant, because the virus multiplied at a low rate in these plants. The remaining tested cultivars were tolerant or susceptible to ZYMV.
\end{abstract}

Zucchini yellow mosaic virus (ZYMV), an economically important virus belonging to the family Potyviridae, genus Potyvirus (17), was discovered simultaneously in Italy (8) and France (7) 30 years ago. The characteristic symptoms of its infection are yellow mosaic pattern on the leaves and deformed fruit of cucurbitaceous vegetables. The virus is easily spread in a nonpersistent manner by aphids and mechanically (9). The virus overwinters in the common weed species Stellaria media (L.) Vill,. Tripleurospermum maritimum (L.) Sch. Bip., and Trifolium repens L. in the Czech Republic (19). Protection against ZYMV is difficult to achieve, and the problem may be solved by the use of resistant cultivars.

Resistance to ZYMV has been reported in cucumber, melon, and squash. In cucumber (Cucumis sativus L.), a single recessive gene for ZYMV resistance was described in the Chinese cucumber 'Taichung Mou Gua-1' (TMG-1) by Provvidenti (14); this cultivar was resistant to $173 \mathrm{ZYMV}$ isolates collected from around the world (6). Provvidenti (15) also identified the accession PI 595203 of Egusi watermelon (Citrullus lanatus Thunb.) as being highly resistant to ZYMV, Watermelon mosaic virus-2, and Cucumber mosaic virus. The butternut squash (Cucurbita moschata Duchesne) landrace 'Menina 15' from Portugal carries a single dominant gene for ZYMV resistance (4). Summer squash (Cucurbita pepo L. convar. giromontiina Grebenščikov) 'Cougar', 'Dividend', 'Hurakan', 'Jaguar', 'Puma', 'Revenue', and 'Tigress' from the United States were bred for ZYMV resistance, with the source of the resistance being another ZYMV-resistant $C$. moschata landrace referred to as 'Nigerian Local' (16).

The objective of the present study was to evaluate selected cultivars and recently bred cucurbitaceous vegetables for their resistance to the Czech highly virulent strain ZYMV-H. This strain was chosen as the most virulent among six different Czech isolates (19). ZYMV-H induces extreme deformation of the leaf lamina,

Corresponding author: J. Svoboda, E-mail: jiri.svo@vurv.cz

Accepted for publication 25 March 2013.

http://dx.doi.org/10.1094/PDIS-11-12-1009-RE

(C) 2013 The American Phytopathological Society yellow mosaic patterns, shoestringing, puckering, and stunting of infected susceptible $C$. pepo plants, which then produce malformed, lumpy fruit.

\section{Materials and Methods}

Plant material. The commercially available seed and recent breeds were obtained from the following sources: Bohemiaseed, Czech Republic: pickling cucumber (Cucumis sativus L.) 'Berdine F1' and slicing cucumber (C. sativus L.) 'Dasher II F1'; Clause Tézier Semences, France: summer squash (Cucurbita pepo L. convar. giromontiina Grebenščikov) 'Alice F1', 'Datcha F1', 'Sofia', 'Zara F1', and breeds 'C63.27' and 'CLX 29 235'; Cucumber Breeding and Seed Production, Ing. B. Holman, Czech Republic: pickling cucumber 'Admira F1', 'Duet F1', 'Fatima F1', 'Lada F1', 'Regina F1', and 'Vigora', breed 'BH-502', and slicing cucumber 'Natalie F1' and 'Viktorie F1'; Harris Moran Seed Company, CA: summer squash Jaguar, Cougar, and Hurakan; INRA, Department of Plant Pathology, Montfavet, France: Chinese slicing cucumber TMG-1 and summer squash 'Xsara'; Institute for Agrobiotechnology, Tulln, Austria: butternut squash (C. moschata Duchesne) Menina 15; MoravoSeed, Czech Republic: pickling cucumber 'Othello F1' and slicing cucumber 'Marta F1' and 'Saladin F1'; Rijk Zwaan, The Netherlands: pickling cucumber 'Harmonie F1', 'Melody F1', and 'Sequenza F1'; Saitama Gensyu Ikuseikai Company, Japan: Japanese slicing cucumber 'Sagamihanjiro fushinari' and breeds 'A192-18', 'A202-18', 'G22', 'R10', and 'S93-18'; SEMO, Czech Republic: slicing cucumber 'Emilie F1', 'Formule F1', 'Lili F1', and 'Minisprint F1'; Seva Flora, Czech Republic: summer squash 'Zelená'; and United States Department of Agriculture (USDA), Plant Genetic Resources Conservation Unit, Griffin, GA: watermelon (Citrullus lanatus Thunb.) accession PI 595203.

ZYMV inoculum. The highly virulent strain ZYMV-H was selected from six isolates collected from various Czech locations. The isolates were distinguished by their pathogenicity on indicator plants. The isolate from the village Hrušky, named ZYMV-H, was the most severe isolate (19). The molecular diversity of the collected ZYMV isolates was assessed (5) and the nucleotide sequence ZYMV-H was deposited in the National Center for Biotechnology Information (NCBI) GenBank database under acces- 
sion number DQ144054. The ZYMV-H strain is maintained in the Crop Research Institute, Prague (18).

Mechanical inoculation. The inoculum was prepared using $1 \mathrm{~g}$ of fresh young leaves from Cucurbita pepo plants systemically infected with the ZYMV-H strain by homogenizing using a mortar and pestle with $3 \mathrm{ml}$ of $0.03 \mathrm{M} \mathrm{Na}_{2} \mathrm{HPO}_{4}$ containing $0.2 \%$ sodium diethyldithiocarbamate (DIECA), $\mathrm{pH} 9.3$ (10). All of the chemicals and vessels used were prechilled and the inoculum was maintained on ice until the inoculation was completed. Active charcoal and carborundum (200 mesh) were added to the homogenate, and the seedling cotyledons were then rubbed with fingers (in latex gloves) wetted down in the homogenate. The plants were kept for $24 \mathrm{~h}$ before the inoculation in darkness to improve the transmission efficiency. After inoculation, the plants were sprayed with distilled water and grown in a greenhouse under a light and dark photoperiod of 14 and $10 \mathrm{~h}$ at 25 and $20^{\circ} \mathrm{C}$, respectively. Young true leaves were collected for enzyme-linked immunosorbent assay (ELISA) 4 weeks after the inoculation, and the ZYMV titer was assessed. The plants were grown for another 2 months and the viral symptoms were evaluated.

The inoculation experiments were conducted twice using 10 plants per cultivar and 2 plants of susceptible summer squash Zelená, which were added to each trial as the control for the infectiousness of the inoculum. The internal standards, moderately resistant slicing cucumber Lili F1 and susceptible pickling cucumber Melody F1, were included in each inoculation trial to normalize the data among the experiments.

Determination the ZYMV titer. The direct double-antibody sandwich ELISA method (1) and specific polyclonal antibodies (Loewe Biochemica) were used for the assignment of the relative concentration of the viral proteins in the leaves of the inoculated plants. The samples for ELISA were prepared by grinding $0.3 \mathrm{~g}$ of

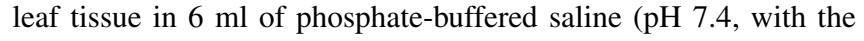
addition of $2 \%$ polyvinylpyrrolidone and $0.2 \%$ bovine albumin). A dilution series of each sample was prepared using the same buffer. One of the internal standards diluted in the same way was pipetted into each ELISA microtiter plate to normalize the evaluation of the titer. The internal standard Suc was used for evaluation the samples taken from susceptible plants and Res for the resistant ones. The plates were incubated for $1 \mathrm{~h}$ at $20^{\circ} \mathrm{C}$ after pipetting the substrate solution. The color reaction was screened using an MR 5000 (Dynatech) reader at $405 \mathrm{~nm}$. The titer of the virus in the leaves was determined as the highest dilution resulting in a positive reaction by ELISA at 4 weeks after the mechanical inoculation; the tests were repeated twice. ELISA was performed using mixed leafy samples of 10 plants per cultivar to average the deviations among the individual plants. When a cultivar was evaluated as immune (i.e., the sample was negative in ELISA), the result was confirmed by electron microscopy and polymerase chain reaction (PCR).

Calculation of the relative $Z Y M V$ concentration. The concentration of ZYMV protein in the leaves $(c)$ is inversely related to the titer $(t)$ (i.e., the smaller the titer, the higher the concentration). Consequently, the concentration can be calculated as a specific constant $(k)$ divided by the titer: $c=k / t$.

It is not necessary to know the exact value of the constant $k$ for the comparison of concentrations of the same viral protein because it is identical for each plant using the same method and determining the same virus. Thus, the compared concentrations are represented by the relationship $c_{1}: c_{2}=1 / t_{1}: 1 / t_{2}$. The reciprocal value of the titer $(1 / t)$ can be assumed for the relative concentration, which is not the exact value of the ZYMV protein concentration in the leaves but is in the proper relation to the other relative concentrations. The relative concentrations $(1 / t)$ are displayed on the vertical axis of the figures to compare the rate of multiplying the virus in the evaluated plants. This calculation was used previously (20).

Electron microscopy. Fresh leaf samples were ground in a mortar with 0.01 M 2-[4-(2-hydroxyethyl)piperazin-1-yl]ethanesulfonic acid buffer, $\mathrm{pH} 8.2$, in a ratio of 1:2. The homogenate was filtered through a silon sieve and negatively stained by the addition of phosphotungstenic acid at a ratio of 1:1, $\mathrm{pH}$ 6.9. The mixture was absorbed to carbon-coated grids, which were observed by means of a 208S (Philips) transmission electron microscope. The samples were evaluated in comparison with ones containing ZYMV particles taken from the internal standard Res.

RNA extraction and TaqMan real-time reverse-transcription (RT)-PCR. The total RNA of infected plant leaves was extracted using the High Pure Viral Nucleic Acid Kit (Roche) according to the manufacturer's protocol, with slight modifications (3). The quality and the concentration of RNA were determined spectrophotometrically using a Gene Quant spectrophotometer (Amersham Pharmacia).

Primers were developed on the basis of the DNA sequence of the gene for viral coat protein of the published Czech ZYMV strains $\mathrm{H}, \mathrm{K}$, and $\mathrm{L}(5)$. The sequences were obtained from the NCBI GenBank database (DQ144061, DQ144055, DQ124244, DQ144062, DQ144054, DQ12445, DQ144063, DQ144056, and DQ124246), and the sequence alignment was performed using the GCG Accelrys database package. The consensus sequence was used for the design of the primer pairs with the Primer Express software 1.5 (Applied Biosystems). The sequences of the primers were homology searched (21) to ascertain the specificity of amplification. The amplicons were verified by sequencing analysis. Before sequencing, the RT-PCR products were purified using the Mini Elute PCR Purification Kit (Qiagen), cloned into pGEM-T Easy vectors (Promega Corp.), and sequenced using the BigDye Terminator Kit (v. 3.1; Applied Biosystems). The unincorporated ddNTPs and primers were removed using the BigDye XTerminator Purification Kit (Applied Biosystems). The sequencing products were resolved using the ABI PRISM 3130 sequencer (Applied Biosystems), and the sequence alignments were assembled using T-Coffee software (12) and the GCG Accelrys software package (Accellrys Software Inc.). The consensus sequence for the ZYMV genotype was searched using NCBI Blast software (20). The primers and TaqMan MGB probe designed and optimized for the detection of ZYMV are as follows: ZYMV-F, 5'-AAACCA ATGGCTATCCAGATTTG-3'， ZYMV-R， 5'-CCATGAATTGTG CAGTTGCTTT-3', and ZYMV-probe, 5'-6-fam-CGATATGAG GGAAAAAATGTATG-3'.

The RNA of the tested samples was transcribed into cDNA using TaqMan Reverse Transcription Reagents (Applied Biosystems). Each reaction was performed in a $50-\mu 1$ reaction volume comprising $1 \times \mathrm{RT}$ buffer, $5.5 \mathrm{mM} \mathrm{MgCl}_{2}, 500 \mu \mathrm{M}$ each dNTP, $1 \mu \mathrm{M}$ oligo dT, $20 \mathrm{U}$ of RNase Inhibitor, 12.5 U of Multiscribe Reverse Transcriptase, and $500 \mathrm{ng}$ of template RNA (in $5 \mu \mathrm{l}$ ). The RT-PCR was performed using the SensoQuest Labcycler (Biomedizinische Elektronik). The reaction scheme consisted of $10 \mathrm{~min}$ at $25^{\circ} \mathrm{C}, 30$ $\min$ at $48^{\circ} \mathrm{C}$, and $5 \mathrm{~min}$ at $95^{\circ} \mathrm{C}$.

The following TaqMan real-time PCR reactions were performed in a $25-\mu$ reaction volume consisting of $1 \times$ PCR buffer, $4 \mathrm{mM}$ $\mathrm{MgCl}_{2}, 100 \mu \mathrm{M}$ each dNTP, $1.25 \mathrm{U}$ of AmpliTag Gold polymerase (Applied Biosystems), $0.3 \mu \mathrm{M}$ each primer, $0.2 \mu \mathrm{M}$ TaqMan MGB probe, and $2 \mu$ of RT reaction mixture. The PCR was performed using the ABI PRISM 7900 cycler in MicroAmp optical 96-well plates (Applied Biosystems). The reaction consisted of $10 \mathrm{~min}$ at $95^{\circ} \mathrm{C}$ and 50 cycles of $94^{\circ} \mathrm{C}$ for $30 \mathrm{~s}$ and $60^{\circ} \mathrm{C}$ for $1 \mathrm{~min}$. The Sequence Detection Software (Applied Biosystems) collected data for the reported dye every $7 \mathrm{~s}$ from each well, generating a fluorescence profile for each reaction. The threshold cycle $(\mathrm{Ct})$ was recorded for each dye as the cycle at which the fluorescent signal, as associated with an exponential growth of the PCR product, significantly exceeded the background fluorescence.

PCR controls were included in every assay. As positive controls, samples extracted from the internal standard Res plants infected ZYMV-H, and plasmids containing target PCR product in eightfold serial dilution steps were included in quadruplet in each plate. A standard curve for the ZYMV content was generated by plotting the logarithm of the plasmid standard dilutions against the $\mathrm{Ct}$ values collected by the Sequence Detections Systems software, and the regression equation was calculated. No-template and no-virus (negative) controls were included in two repetitions in each real- 
time RT-PCR. If the $\mathrm{Ct}$ values were equal to or more than 50, the ZYMV content in those samples was considered to be undetectable.

\section{Results}

Kinetics. First, we studied the kinetics of ZYMV infection in plants. Four summer squash (Cougar, Hurakan, Jaguar, and Zelená) with different levels of resistance to ZYMV (follows in this study) were mechanically inoculated with ZYMV-H and then tested using ELISA for the level of the relative ZYMV protein concentration during 17 weeks after inoculation (Fig. 1). The tests showed the highest differences in the relative virus concentration (RVC) at the fourth week after inoculation. Thereafter, the RVC maintained a constant level or first increased and then reached a constant level. In the case of Hurakan, the RVC was at a constant level after the fourth week until the eighth week and then decreased, remaining much more reduced than the RVC of the other cultivars. Similarly, in the case of susceptible summer squash Zelená, its high RVC stayed at a constant level until the tenth week and then decreased, remaining reduced at the same level as the RVC of Cougar and Jaguar. These results were compared with the observations of the ZYMV symptoms on the leaves and fruit of the tested plants. The susceptible plants showed symptoms of the ZYMV infection after 10 or 14 days. Four weeks after inoculation, summer squash Cou- gar and Jaguar showed systemic mosaic symptoms of mild and medium intensity, respectively, on their leaves. Plants of Hurakan showed more severe mosaic symptoms, with some leaf deformations, than Cougar and Jaguar. Plants of the susceptible control Zelená were markedly more damaged, even stunted, and had severe mosaic patterns on the severely deformed shoestringed leaves, with simultaneous dark green blisters. The differences in the observed symptoms were in agreement with the RVC differences determined at 4 weeks after inoculation.

Summer squash. The results of the evaluation of the selected summer squash cultivars for ZYMV resistance, as obtained from two trials and based on the RVC determined at the fourth week after inoculation, are shown in Figure 2. The tests were completed by observing the viral symptoms of the tested plants. Of note, Cougar showed the smallest RVC, followed by Jaguar, Xsara, and Hurakan. The infection of ZYMV resulted in only mild symptoms on the leaves of summer squash Cougar, and its fruit were not deformed. In our tests, Cougar was evaluated as resistant. Jaguar and Xsara showed mild mosaic patterns and several yellow spots on leaves, respectively, with rarely deformed fruit; these cultivars were evaluated as moderately resistant. Summer squash Hurakan was evaluated as moderately susceptible; the RVC in its leaves was twice as high as Jaguar and Xsara, and its fruit were slightly deformed. Based on their RVC values, all of the other evaluated sum-

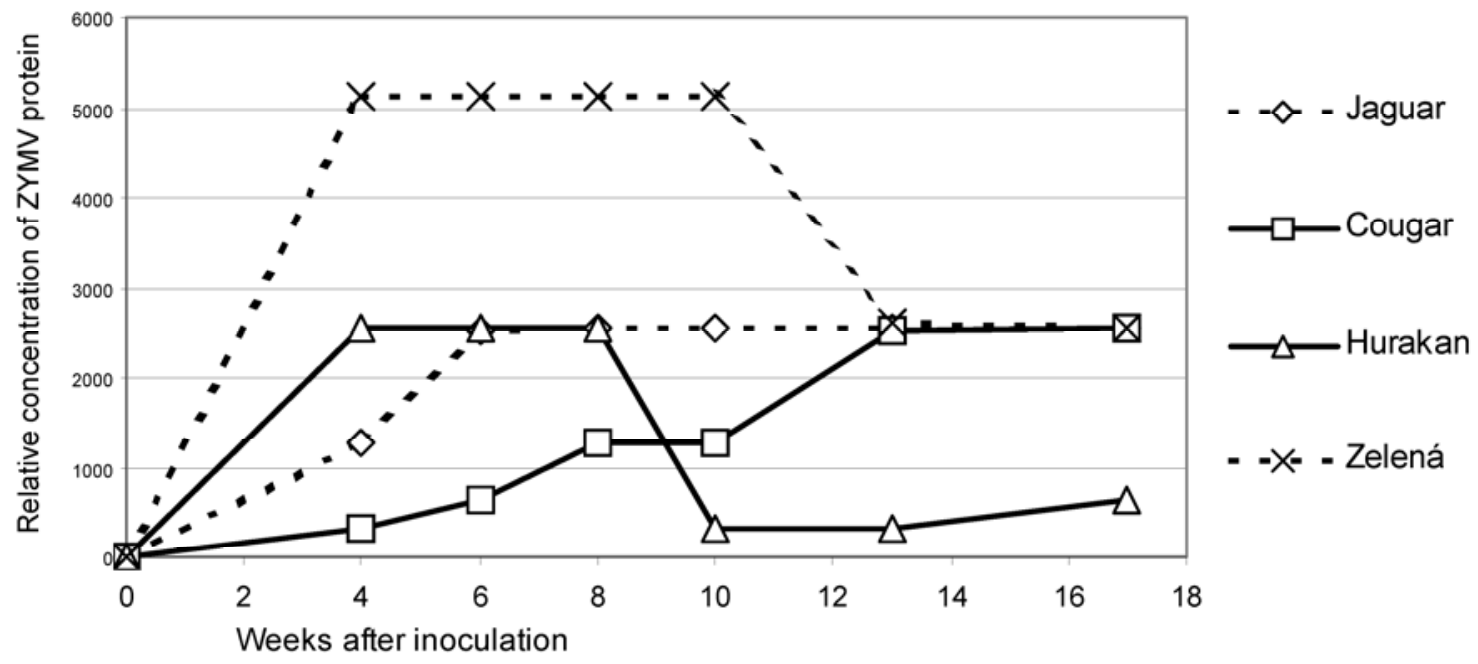

Fig. 1. Kinetics of the development of Zucchini yellow mosaic virus (ZYMV) concentrations in summer squash.

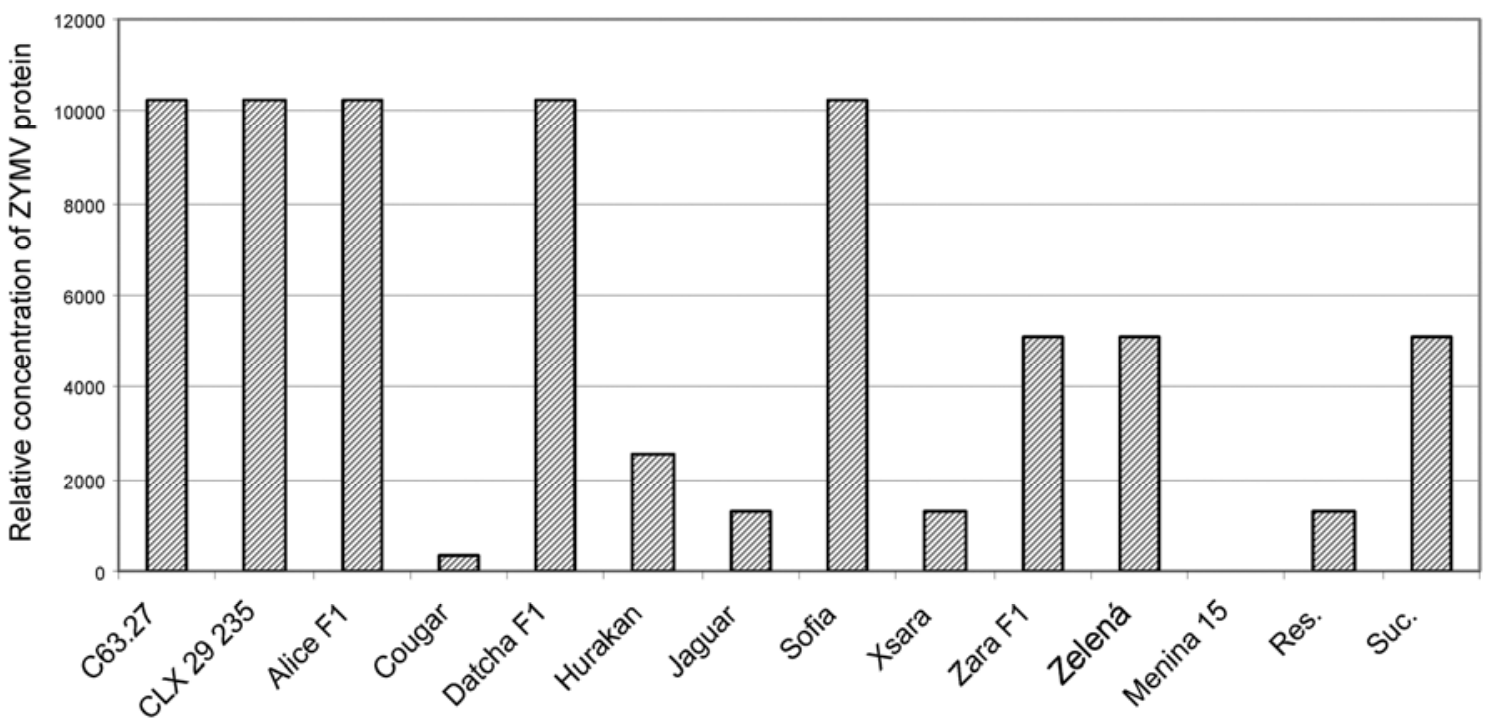

Fig. 2. Comparison of Zucchini yellow mosaic virus (ZYMV) concentrations in summer and butternut squash. Internal standards Res and Suc were used for evaluation of the samples taken from resistant and susceptible plants, respectively. 
mer squash cultivars were highly susceptible: their RVCs were at least twice as high as Hurakan but the fruit of cultivars Alice F1, Sofia, and breed C63.27 were nearly without any deformation and, thus, were assessed as tolerant. The remaining evaluated summer squash, Datcha F1, Zara F1, Zelená, and breed CLX 29 235, had severely deformed fruit and leaves with shoestringing and mosaic symptoms, which was often followed by the premature death of the plant. These cultivars were assessed as highly susceptible.

Pickling cucumber. No cultivar from the selected pickling cucumber lines was evaluated as resistant; all of them had minimum RVC levels that were the same as summer squash Jaguar and Xsara (Fig. 3). Regina F1 and breed BH-502 were assessed as moderately resistant, showing only mild mosaic patterns or diffuse yellow spots on their leaves and yielding nondeformed fruit. Their RVCs were the lowest of the tested pickling cucumber at four times lower than in the susceptible pickling cucumber Berdine F1, Duet F1, Fatima F1, Harmonie F1, or Melody F1, which showed systemic mosaic patterning, with occasionally severe mosaic patches on their leaves, and produced mostly deformed lumpy fruit. Pickling cucumber Admira F1, Lada F1, Othello F1, Sequenza F1, and Vigora, with RVCs twice as high as the moderately resistant cultivars, developed mosaic symptoms on their leaves and produced frequently deformed fruit. Among them, the cucumber with barely warted fruit (Othello F1, Sequenza F1, and Vigora) were evaluated as susceptible because they were much more damaged both on the leaves and fruit than Admira F1 and Lada F1 which, with coarsely warted, mostly symptomless fruit, were considered as moderately tolerant.

Slicing cucumber. Among the tested slicing cucumber lines, Japanese breeds A202-18, R10, and S93-18 were evaluated as resistant cultivars (Fig. 4). Their RVCs were at least 16 times lower than in the susceptible slicing cucumber Sagamihanjiro fushinari or Marta F1 and 4 times lower than in the moderately resistant pickling cucumber Regina F1 and BH-502. Moreover, these plants did not develop any ZYMV symptoms on the leaves or fruit, in comparison with cucumber Sagamihanjiro fushinari and Marta F1, which showed systemic mosaic with dark green blisters on their leaves and produced deformed lumpy fruit, if any. Emilie F1 and

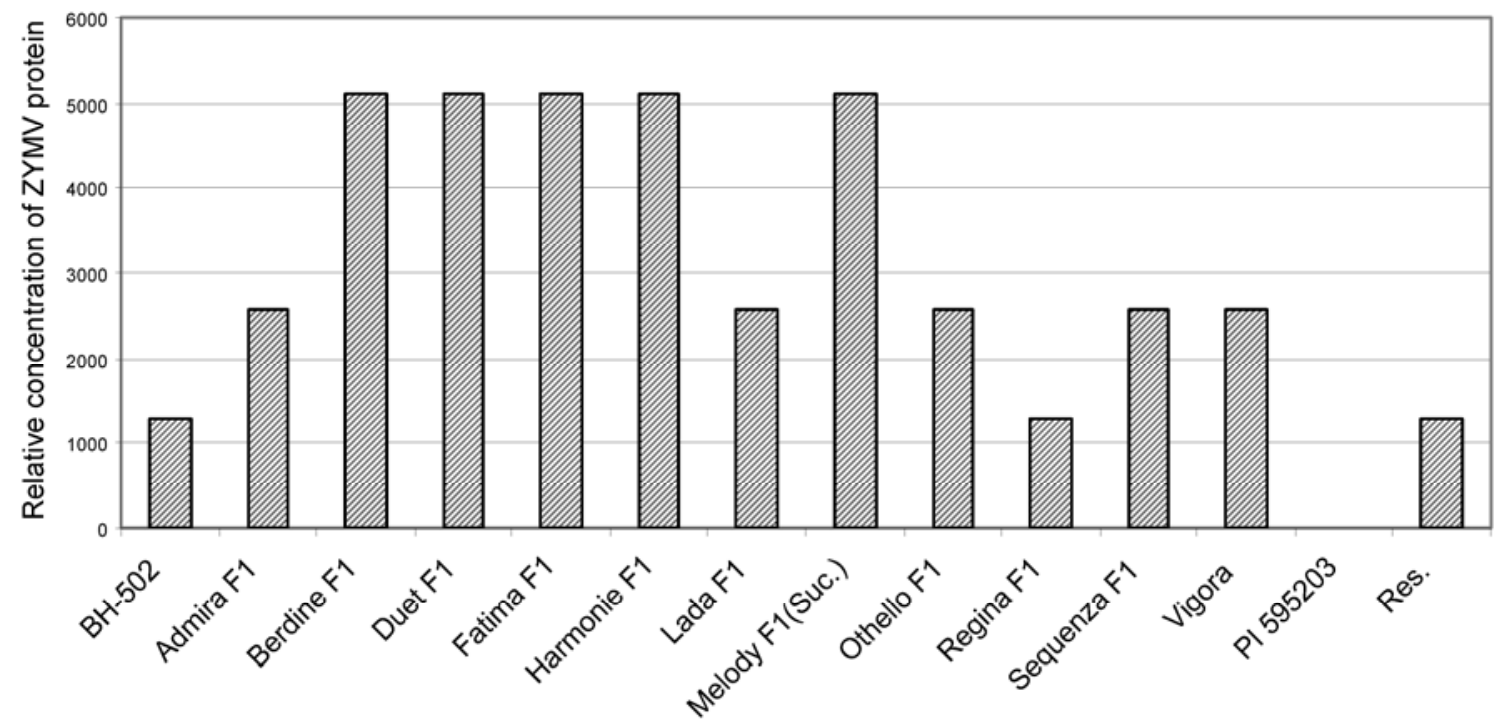

Fig. 3. Comparison of Zucchini yellow mosaic virus (ZYMV) concentrations in pickling cucumber and watermelon. Internal standard Res was used for evaluation of the samples taken from resistant plants.

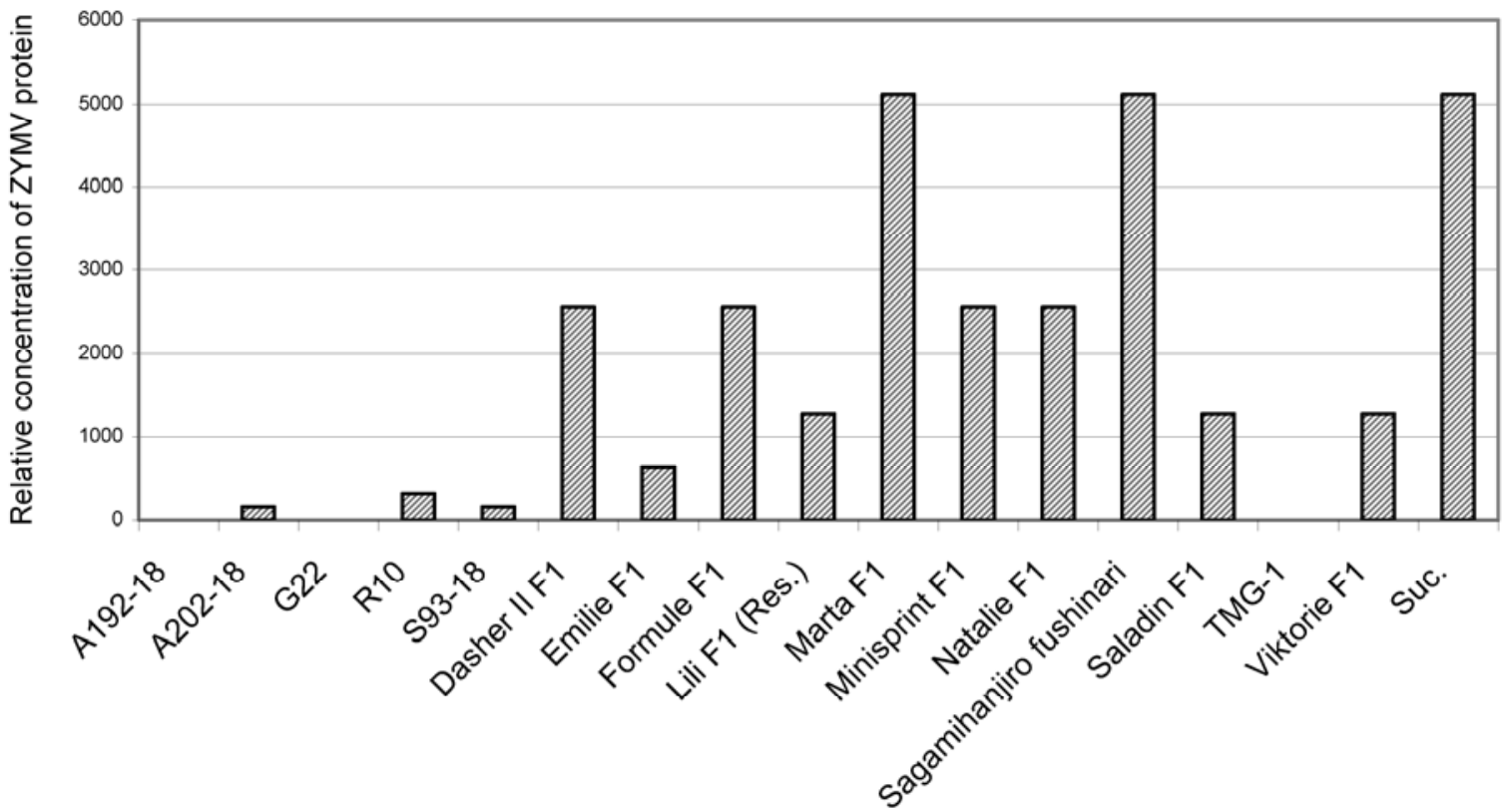

Fig. 4. Comparison of Zucchini yellow mosaic virus (ZYMV) concentrations in slicing cucumber. Internal standard Suc was used for evaluation of the samples taken from susceptible plants. 
Lili F1, with RVCs at a minimum of four times lower than in the susceptible cucumber, displayed mild mosaic symptoms on their leaves and yielded nondeformed fruit; they were evaluated as moderately resistant. All of the other tested slicing cucumber (Dasher II F1, Formule F1, Minisprint F1, Natalie F1, Saladin F1, and Viktorie F1) had RVCs two or four times lower than the above susceptible slicing cucumber cultivars, showed mosaic symptoms on their leaves, and produced mostly deformed fruit, often with diffuse yellow spots. These cultivars were also evaluated as susceptible cucumber cultivars.

Immune species. There were five species that had RVCs after ZYMV inoculation equal to zero (i.e., they were ELISA negative): butternut squash Menina 15, Chinese slicing cucumber TMG-1, Japanese slicing cucumber breeds G22 and A192-18, and watermelon PI 595203 (Figs. 2-4). Two inoculation trials were performed with the same result; therefore, their leaf samples were examined by electron microscopy, which did not reveal any viral particles.

A biological test was performed as a second confirmation of immunity. Young leaves from these plants were collected at 4 weeks after the ZYMV inoculation, and mechanical transmission onto the susceptible summer squash Zelená (five plants per tested cultivar) was performed. The inoculated Zelená plants did not show any viral symptoms for another month and were negative by ELISA.

Consequently, the absence of ZYMV in these plants was verified by a TaqMan real-time RT-PCR assay that was designed and validated for this purpose. The specificity of the primers and TaqMan probe were confirmed by amplification of a DNA fragment of the expected size (109 bp) and the increase of the fluorescence signal for ZYMV-positive standards. Because the TaqMan real-time RTPCR assay was used to detect a very low content of viral RNA, the number of cycles was increased from 40 to 50. Compared with the average $\mathrm{Ct}$ value 34 of the internal standard Res, the $\mathrm{Ct}$ values of samples butternut squash Menina 15, Chinese slicing cucumber TMG-1, Japanese slicing cucumber breeds G22 and A192-18, and watermelon PI 595203 were recorded to be higher than 50 and, therefore, were considered to be negative for the presence of ZYMV. These cultivars were clearly found to be superior to all of the other tested cucurbitaceous vegetables and were evaluated as immune.

\section{Discussion}

The introduction of effective ZYMV-resistant cultivars of cucurbitaceous vegetables would be a vital contribution for vegetable growers worldwide. To this end, the selection of the virus strain is important when performing resistance tests. The existence of weak ZYMV strains that develop only mild symptoms, if any, on inoculated plants is not surprising $(2,19)$. We used the most severe Czech strain ZYMV-H to allow us to examine the resistance of truly resistant or even immune plants. When this strain was characterized at the nucleic acid level and compared with the sequences of eight Slovak isolates and with those of the NCBI GenBank database, a low level of genetic diversity within the central European ZYMV isolates was observed (5). This finding allowed us to use ZYMV-H as a virulent representative of central European ZYMV strains.

Similarly, the choice of the exact time period after inoculation was significant for the testing of the plants because, as shown in Figure 1, the differences in the RVCs among susceptible and resistant summer squash cultivars can narrow, regardless of the continued intensification of symptoms on the susceptible cultivars whose RVCs mostly decreased or remained at a constant level from the 10th week after inoculation. The plants were not healthier with aging but, rather, displayed even more severe symptoms, particularly the susceptible cultivars. The detected differences in the disease progress were interesting. It seems that the resistant summer squash Cougar and Jaguar possess some specific defense mechanism which starts to work immediately after the infection whereas the susceptible summer squash Hurakan and Zelená are not able to suppress virus multiplication until after some time lag. Four weeks after inoculation was a sufficient duration, though not too long, to reach the maximal RVC differences among the cultivars in accordance with the observed symptoms on evaluated plants. As the determined RVCs show, ZYMV generally multiplied to a lesser degree in the older plants versus the young plants.

With regard to the performed resistance tests, it should be noted that there were some differences in the RVC among the individual plants of a single cultivar. The standard deviations calculated for eight plants of each summer squash (Cougar, Hurakan, Jaguar, and Zelená) at the fourth week after the inoculation were $72,37,42$, and $41 \%$, respectively, suggesting the possibility that a further increase in resistance would be possible by selection.

In contrast, some of the tested cultivars did not display severe symptoms despite the fact that high values of RVC were detected. However, viral multiplication occurred; therefore, these plants were considered to be tolerant rather than susceptible (11). Accordingly, the evaluation of ZYMV resistance cannot be based only on the determination of the RVC in plants but also must be accompanied by the observation of symptoms.

Our evaluation of pickling cucumber is in agreement with a previous report (13), in which a field ZYMV-resistance trial of 40 selected cultivars of pickling cucumber was performed by assessing the percentage of damaged leaf surface by ZYMV infection and the market yield of fruit. In that experiment, the plants of cucumber Melody F1 and Sequenza F1 belonged to the group with the most damaged leaves (65 to $80 \%$ of the surface). Cucumber Fatima F1 produced nearly the lowest yield ( 0.5 to $0.6 \mathrm{~kg} / \mathrm{plant})$, as opposed to Duet F1 and Regina F1, with the highest yield (2.5 to $3.5 \mathrm{~kg} / \mathrm{plant}$ ), in good accordance with our results, with the exception of cucumber Duet F1. However, the fact that the RVC values detected in Duet F1 were four times higher than in Regina F1 in our study suggests that Duet F1 belongs to the ZYMV-tolerant group of cultivars.

Among the tested susceptible cucumber lines, slicing cucumber Formule F1, Minisprint F1, and Saladin F1, with smooth, thornfree skin, similar to pickling cucumber Othello F1, Sequenza F1, and Vigora, with barely warted fruit, exhibited much more damage on both leaves and fruit than the slicing cucumber with sparsely thorny fruit such as Dasher II F1, Natalie F1, and Viktorie F1 and coarsely warted pickling cucumber Admira F1 and Lada F1. Hence, we suggest that thorny fruit in cucumber cultivars are indicative of a higher level of tolerance to ZYMV infection. Further experiments to address this question should be performed in the future.

Summary. In this work, we endeavored to conduct a more comprehensive investigation of resistance among selected cucurbits than had been previously performed. Based on the detection of RVC (Figs. 2-4), our results demonstrate that the method used is an essential tool for the evaluation of resistance. When compared with the assessment based on the observation of symptoms, our method is more quantitative and produces more exact correlation among cultivars, with the exception of tolerant plants with a high RVC level and mild symptoms. The evaluation of resistance to ZYMV will continue with further research.

\section{Acknowledgments}

This work was supported by project MZe0002700604 of the Ministry of Agriculture, Czech Republic. We thank H. Lecoq from INRA, Montfavet, France; M. Pachner from the Institute for Agrobiotechnology, Tulln, Austria; F. Tiffany from USDA, Plant Genetic Resources Conservation Unit, Griffin, GA; C. Tézier Semences, France; Cucumber Breeding and Seed Production Ing. B. Holman, Czech Republic; and Harris Moran Seed Company, Modesto, CA for furnishing seed of cucurbitaceous vegetables.

\section{Literature Cited}

1. Clark, M. F., and Adams, A. N. 1977. Characteristic of the microplate method of enzyme-linked immunosorbent assay for the detection of plant virus. J. Gen. Virol. 34:475-483.

2. Desbiez, C., Wipf-Scheibel, C., and Lecoq, H. 2002. Biological and serological variability, evolution and molecular epidemiology of Zucchini yellow mosaic virus (ZYMV, Potyvirus) with special reference to Caribbean islands. Virus Res. 85:5-16.

3. Dovas, C. I., Hatziloukas, E., Salomon, R., Barg, E., Shiboleth, Y., and Katis N. I. 2001. Comparison of methods for virus detection in Allium spp. 
J. Phytopathol. 149:731-737.

4. Gilbert-Albertini, F., Lecoq, H., Pitrat, M., and Nicolet, J. L. 1993. Resistance of Cucurbita moschata to watermelon mosaic virus type 2 and its genetic relation to resistance to zucchini yellow mosaic virus. Euphytica 69:231-237.

5. Glasa, M., Svoboda, J., and Nováková, S. 2007. Analysis of the Molecular and Biological Variability of Zucchini yellow mosaic virus isolates from Slovakia and Czech Republic. Virus Genes 35:415-421.

6. Lecoq, H., Desbiez, C., Wipf-Scheibel, C., Girard, M., and Pitrat, M. 2002. Durability of zucchini yellow mosaic virus resistances in cucurbits. Pages 294-300 in Cucurbitaceae 2002. D. N. Maynard, ed. ASHS Press, Alexandria, VA.

7. Lecoq, H., Pitrat, M., and Clément, M. 1981. Identification et caractérisation d'un potyvirus provoquant la maladie du rabougrissement jaune du melon. Agronomie 1:827-834.

8. Lisa, V., Boccardo, G., D’Agostino, G., Dellavalle, G., and d'Aquilio M. 1981. Characterisation of a potyvirus that causes zucchini yellow mosaic. Phytopathology 71:667-672.

9. Lisa, V., and Lecoq, H. 1984. Zucchini yellow mosaic virus. CMI/AAB Descriptions of Plant Viruses No. 282. Unvin Brothers Press, Surrey, UK

10. Mahgoub, H. A., Desbiez, C., Wipf-Scheibel, C., Dafalla, G., and Lecoq, H. 1997. Characterization and occurrence of zucchini yellow mosaic virus in Sudan. Plant Pathol. 46:800-805.

11. Matthews, R. E. F. 1991. Plant Virology, 3rd ed. Academic Press, San Diego, CA.

12. Notredame, C., Higgins, D., and Heringa, J. 2000. T-Coffee: a novel method for multiple sequence alignments. J. Mol. Biol. 302:205-207.
13. Petř́ková, K., Nakvasil, V., and Pokluda, R. 2005. Zhodnocení sortimentu okurek nakládaček na rezistenci k ZYMV. Pages 11-16 in: Sborník přednášek ze semináře "Metodika pro integrovaný systém ochrany polnú zeleniny vůči škodlivým organismům”. Crop Research Institute, Prague, Czech Republic.

14. Provvidenti, R. 1987. Inheritance of resistance to a strain of zucchini yellow mosaic virus in cucumber. HortScience 22:102-103.

15. Provvidenti, R. 1991. Inheritance of resistance to the Florida strain of zucchini yellow mosaic virus in watermelon. HortScience 26:407-408.

16. Provvidenti, R. 1997. New American summer squash cultivars possessing a high level of resistance to a strain of zucchini yellow mosaic virus from China. Cucurbit Genet. Coop. Rep. 20:57-58.

17. Regenmortel, M. H. V., Fauquet, C. M., Bishop, D. H. L., Carstens, E. B., Estes, M. K., Lemon, S. M., Maniloff, J., Mayo, M. A., McGeoch, D. J., Pringle, C. R., and Wickner, R. B. 2000. Virus Taxonomy. Pages 706-712 in: Seventh Report of the International Committee on Taxonomy of Viruses. Academic Press, San Diego, CA.

18. Svoboda, J. Virus Collection. Crop Research Institute. http://www.vurv.cz/ collections/vurv.exe/search?org=VI

19. Svoboda, J., and Polák, J. 2002. Distribution, Variability and Overvintering of Zucchini yellow mosaic virus in the Czech Republic. Plant Prot. Sci. 38:125-130.

20. Svoboda, J., and Polák, J. 2010. Relative concentration of Apple mosaic virus coat protein in different parts of apple tree. HortScience (Prague) 37:22-26.

21. Zhang, Z., Schwartz, S., Wagner, L., and Miller, W. 2000. A greedy algorithm for aligning DNA sequences. J. Comput. Biol. 7:203-214. 